\title{
Individualism vs. Group Rights: The Legacy of Brown*
}

\section{William Bradford Reynolds $\dagger$}

There is, I believe, no higher or more important calling than the commitment to education, for to our teachers we entrust the awesome responsiblity of developing America's most precious resource-the minds of our youth. Only if the limits of man's knowledge and understanding are broadened, and the lessons of history learned, will tomorrow's leaders be prepared to detect and correct our errors-in much the same manner that we, gathered here today, strive to identify and profit from the mistakes of our forebears.

On another level, the privilege of education is basic to the full exercise of fundamental constitutional rights. For example, the precious First Amendment right to trade in the "marketplace of ideas" undeniably has less value to those who are educationally ill-equipped to participate fully in the exchange. Similarly, all would concede that education is essential to informed participation in the affairs of government through the right to vote.

Yet, despite the critical importance to all Americans-and to America-of quality education, the decline in educational achievement among our youth has emerged as one of the Nation's most pressing contemporary social issues. Note that I have deliberately refrained from characterizing the issue as one of civil rights-notwithstanding the popular inclination in many quarters, particularly in the courts, to speak of social policy issues as though they are, in essence, civil rights issues. Indeed, there, I submit, lies one of our most fundamental problems today. The contemporary expansion of the traditional concept of civil rights to include a broad array of purely social concerns has failed, in my view, to solve-and has often exacerbated-those very social concerns the expansion was intended to serve while, at the same time, leading in too many instances to an erosion of individual civil rights protections under the Constitution and the landmark legislation of the early 1960's, at least as those measures are traditionally and properly understood.

- This essay was originally delivered as a speech before the Lincoln Institute Conference on September 28, 1983.

$\dagger$ B.A., Yale 1964. J.D., Vanderbilt University School of Law 1967. The author is currently Assistant Attorney General, Civil Rights Division. 
What, you might ask, is the traditional and proper understanding of "civil rights"? Let me, in response, defer to Professor Chester Finn of Vanderbilt University, who observed, in recent testimony before the Senate Judiciary Committee, that:

[C]ivil rights-fundamentally the rights of citizenship, of a member of the polity, ...-inhere in individuals, not in groups. While discrimination against an individual, or the denial of rights to an individual, may occur because the individual has some of the characteristics of a particular group-such as gender, color, religion, etc.,-the inalienable rights themselves inhere in the individual, and any abridgement of them is an act of discrimination against the individual. That is a fundamental principle of democracy. It is explicit in the Declaration of Independence, the Constitution (perhaps especially in the Bill of Rights) and in the major civil rights legislation over the decades. To be sure, there have been all too many occasions in our history where acts of discrimination were perpetrated against many or all of the individuals in a particular group, but it is nonetheless the individuals who were discriminated against. ${ }^{1}$

There are those who, rather unabashedly, have undertaken to redefine this traditional concept of civil rights. The essential concern for individual opportunity, so correctly underscored by Professor Finn, has been submerged by this school of thought beneath a rising tide of group entitlements. The Civil Rights Commission, to cite but one example, has in recent years been in the forefront of this movement-endorsing, in many of its reports and pronouncements, approaches geared to group improvements at the expense of individual initiative. To me-as to many others-such an approach reflects a fundamental distortion of civil rights in a democratic society, and I would like to spend a few pages sharing some thoughts on this subject in the hope that they will foster a better understanding and appreciation for Administration policy in the sensitive and critically important area of civil rights.

Let me start with the interesting observation that many of those who over the past decade have sought fervently to propel civil rights enforcement along a group-oriented course are the same men and women who were in the vanguard of the great civil rights movement of the 1950's and 1960 's - the movement that, for the first time, put individual rights on the pedestal reserved for them by the Founders of this great country and the Framers of our Constitution. To be sure, the "distancing," if you will,

1. A Bill to Amend the Civil Rights Act of 1957 to Extend the Life of the Commission on Civil Rights, and for Other Purposes, 1983: Hearings on S. 1189 before the Subcomm. on the Constitution of the Sen. Comm. on the Judiciary, 98th Cong., 1st Sess. 20 (1983) (statement of Chester E. Finn, Jr., Professor of Education and Public Policy, Vanderbilt University). 
from the traditional concept of civil rights by some of the original advocates has been gradual, but clearly discernible. A quick look at that evolutionary process is a useful framework to the discussion that follows, particularly here, since the field of education has provided the catalyst for much of the reoriented thinking. While the focus of my remarks will be on race discrimination, what follows applies with equal force to discrimination on account of sex, ethnic origin, and religion.

America's first enduring step towards securing the civil right to nondiscriminatory treatment was, of course, passage of the Thirteenth, Fourteenth, and Fifteenth Amendments, which abolished slavery, guaranteed to all citizens equal protection under the law, and protected the right to vote from racial discrimination. History faithfully records that the purpose of these Amendments was to end forever a system which determined legal rights, measured status, and allocated opportunities on the basis of race, and to erect in its place a regime of race neutrality. Thus, in the 1866 debates on the Fourteenth Amendment, the equal protection clause was described as "abolish[ing] all class legislation in the States [so as to do] away with the injustice of subjecting one caste of persons to a code not applicable to another."2

Thirty years later, in 1896, a Supreme Court Justice, the elder Justice Harlan, correctly recognized that these Civil Rights Amendments had "re-

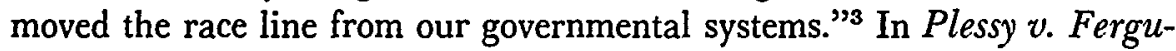
son, he declared: "Our Constitution is colorblind and neither knows nor tolerates classes among citizens ... . The law regards man as man, and takes no account of his surroundings or of his color . . ."."

Unfortunately, as we all know, his was a lone dissenting voice in that case. A majority of the Supreme Court turned back the clock on civil rights, holding that racial distinctions were permitted under the Fourteenth Amendment. The separate-but-equal doctrine formulated by the Plessy majority held sway in America for over half a century, a period in which many state and local governments regulated the enjoyment of virtually every public benefit-from attendance in public schools to the use of public restrooms-on the basis of race. It was not until 1954 that the patent injustice of governmental allocation of benefits along racial lines ultimately-indeed inevitably-brought the Supreme Court to its finest hour: the case of Brown v. Board of Education. ${ }^{5}$

In Brown, the Supreme Court finally laid to rest the separate-but-equal doctrine. The Court acknowledged with eloquent simplicity that the equal

2. Cong. Grobe, 39th Cong., 1st Sess. 2766 (1866) (statement of Sen. Howard).

3. Plessy v. Ferguson, 163 U.S. 537, 555 (1896).

4. Id. at 559 .

5. 349 U.S. 294 (1954). 
protection clause requires governmental race neutrality in all public activities. "At stake," declared Chief Justice Warren for a unanimous Court, "is the personal interest of the plaintiffs in admission to public schools ... on a [racially] nondiscriminatory basis." tool for assigning school children was flatly and unequivocally condemned, and the personal right-the civil right-to nondiscrimination was vindicated.

This judicial insistence on colorblindness in our public school systems was precisely the conclusion urged by the school children's attorney, Thurgood Marshall. Expressly rejecting the notion that the Constitution would require the establishment of "non-segregated school[s]" through race-conscious student reassignments, Mr. Marshall argued to the Court that:

The only thing that we ask for is that the State-imposed racial segregation be taken off, and to leave the county school board, the county people, the district people, to work out their own solution of the problem, to assign children on any reasonable basis they want to assign them on. ${ }^{2}$

So long as the children were assigned "without regard to race or color, . . nobody," argued Mr. Marshall, "would have any complaint."

Thus, both Court and counsel recognized that the civil right at issue-the right to race-neutral assignment-belonged to each individual student and therefore could not be reconciled with the group-oriented notion that the Constitution requires integration through race-conscious student assignments.

The Brown decision spurred a judicial and legislative drive to eliminate racial discrimination in virtually every aspect of American life. Nearly two centuries after the Declaration of Independence recognized the concept of equality as a "self-evident" truth, the principle was finally being written into law. Out of the turmoil, bitter debate, and strife of the 1950's there began to emerge in the 1960's a broad recognition-a consensus-that official colorblindness and equal opportunity for all individuals were not just legal commandments, but moral imperatives, that could no longer be denied.

None was more passionately committed to the colorblind principle of equal opportunity for each individual than the leaders of the civil rights

6. Id. at 300 .

7. Reprinted in Argument: The Oral Argument Before the Supreme Court in Brown v. BoARd of Education of TOPEKA, 1952-55, at 47 (L. Friedman ed. 1969).

8. Id. at 48.

9. Declaration of Independence para. 2 (U.S. 1776). 
movement, who had for so many years courageously marched in bold defiance of those bent on ordering society according to the color of a person's skin. Preferential treatment based on race was intolerable to them, regardless of the purpose. Roy Wilkins, while he was Executive Director of the NAACP, stated the position unabashedly during congressional consideration of the Civil Rights Act of 1964:

Our association has never been in favor of the quota system.

We believe the quota system is unfair whether it is used for [blacks] or against [blacks] . . . . [W]e feel people ought to be hired because of their ability, irrespective of their color ... . We want equality, equality of opportunity and employment on the basis of ability. ${ }^{10}$

Similarly, Jack Greenberg, Director-Counsel of the NAACP Legal Defense Fund, in urging the Supreme Court to invalidate a state statute requiring that a candidate's race be designated on each ballot, argued:

[T]he fact that this statute might operate to benefit a [black] candidate and against a white candidate . . . is not relevant. For, it is submitted that the State has a duty under the Fifteenth Amendment and the Fourteenth Amendment to be "color-blind" and not to act so as to encourage racial discrimination . . . against any racial group. ${ }^{11}$

The Court agreed and struck down the offending statute.

The principle of race neutrality was fully endorsed as well by the Congress of the United States with passage of a series of important new laws designed to make equal opportunity a reality: the Civil Rights Acts of 1957, 1960, and 1964, the Voting Rights Acts of 1965, and the Fair Housing Act of 1968. That Congress intended these enactments to establish a standard blind to color distinctions is reflected in both the statutes' language and their legislative histories. For example, Senator Humphrey, the principal force behind passage of the 1964 Act in the Senate, repeatedly stated that Title VII would prohibit any consideration of race in employment matters, using on one occasion these words:

The title does not provide that any preferential treatment in employment shall be given to Negroes or to any other persons or groups. It does not provide that any quota systems may be estab-

10. Miscellaneous Proposals Regarding the Civil Rights of Persons Within the Jurisdiction of the United Stales, 1963: Hearings on H.R. 7152 before Subcomm. No. 5 of the House Comm. on the Judicinry, 88th Cong., 1st Sess. 2144 (statement of Roy Wilkens).

11. Jurisdictional Statement of Appellants, at 11-12, Anderson v. Martin, 375 U.S. 399 (1964) (emphasis added). 
lished to maintain racial balance in employment. In fact, the title would prohibit preferential treatment for any particular group, and any person, whether or not a member of any minority group, would be permitted to file a complaint of discriminatory employment practices. ${ }^{12}$

Similarly, in the area of school desegregation, the 1964 Congress took special precautions to ensure that Title IV of the same Act was equally faithful to the principle of race neutrality. This was reflected in two separate sections of the legislation: one that plainly states "desegregation" shall not mean the assignment of students to public schools in order to overcome racial imbalance," "13 and another that stresses even more explicitly that the Act does not "empower any official or court of the United States to issue any order seeking to achieve a racial balance . . ."14 Nor did Congress rest there. The 1974 Equal Educational Opportunities Act ${ }^{15}$ includes congressional findings regarding the counterproductive nature of excessive busing to achieve classroom ratios based on race, places limitations on the authority of courts to order such relief, and expresses a strong preference for other remedies-such as neighborhood schools with neutrally drawn zones, transfer programs, magnet schools, and new construction-which better combine the objectives of desegregation and educational improvement. ${ }^{16}$ And this congressional attitude was reaffirmed in the last Congress, when both houses voted overwhelmingly against utilization of the tool of "forced busing" to achieve school desegregation. ${ }^{17}$

These judicial and legislative pronouncements reflect a national consensus that racial classifications are wrong-morally wrong-and ought not to be tolerated in any form or for any reason. Spokesmen both within and outside of government have advanced the principle, but its true essence was best captured, in my judgment, by Dr. Martin Luther King, Jr., when he dreamed aloud in the summer of 1963 of a nation in which his

12. 110 Cong. Rec. 11,848 (1964).

13. Pub. L. No. $88-352, \S 401($ b), 78 Stat. 241,246 (1964) (codified at 42 U.S.C. $\S 2000$ c(b) (1976)).

14. Id. $\S 407($ a), 78 Stat. at 248 (codified at 42 U.S.C. $\S 2000$ c-6 (1976)).

15. Pub. L. No. $93-380, \S \S 201-259,88$ Stat. $484,514-21$ (codified at 20 U.S.C. $\$ \S 1701-1758$ (1982)).

16. Id. $\S 203,88$ Stat. at 514 (codified at 20 U.S.C. 1702 (1982)); id. § 215, 88 Stat. at 517 (codified at 20 U.S.C. $\S 1714$ (1982)); id. $\S 214,88$ Stat. at 517 (codified at 20 U.S.C. $\S 1713$ (1982)).

17. Both Houses of the 97th Congress amended Department of Justice authorization bills to include anti-busing provisions. See H.R. 3462, 97th Cong., 1st Sess., 127 CoNG. Rec. H2787-2805 (daily ed. June 9, 1981); S. 951, 97th Cong., 2d Sess., 127 Cong. Rec. S1317-36 (daily ed. Mar. 2, 1982). Because the two Houses did not agree on the form of the entire authorization bill, however, the amendment did not become law. 
children would "not be judged by the color of their skin, but by the content of their character."18

In the 1970's, however, as I indicated at the outset, the quest for equality of opportunity for individuals began in some quarters gradually to evolve into an insistence upon equality of results for groups. The individual-oriented concept of racial neutrality was blurred into the group-oriented concept of racial balance, on the representation that the former could not be fully realized unless the latter was achieved.

Numerical proportionality among groups became for some a civil right. Regulation and allocation of individuals by race, they argued, are not wrong per se. Rather, their validity depends upon who is being regulated, what is being allocated, and the purpose of the arrangement. If a racial preference will achieve the desired statistical result, its discriminatory feature can be tolerated, we are told, as an unfortunate but necessary consequence of remedying the effects of past discrimination-using race "in order to get beyond racism" is the way one member of the Supreme Court has put it. ${ }^{19}$

The analytical flaw in this approach was laid bare by Professor Alexander Bickel in his extraordinary book, The Morality of Consent. ${ }^{20}$ In precise terms, he responded to such reasoning in the following manner:

The lesson of the great decisions of the Supreme Gourt and the lesson of contemporary history have been the same for at least a generation: discrimination on the basis of race is illegal, immoral, unconstitutional, inherently wrong, and destructive of democratic society. Now this is to be unlearned and we are told that this is not a matter of fundamental principle but only a matter of whose ox is gored . . . . Having found support in the Constitution for equality, [proponents of group-oriented racial preferences] now claim support for inequality under the same Constitution. ${ }^{21}$

Another champion of equal opportunity and individual liberty, Justice William O. Douglas, was no less adamant in his rejection of grouporiented, race-conscious solutions. In 1974, in connection with the first case to come before the Supreme Court involving the allegedly benign use of race to allocate among racial groups the limited number of places in a professional school, Justice Douglas stated: "The Equal Protection Clause commands the elimination of racial barriers, not their creation in order to

18. C. King, My Life with MARTin Luther King, JR., 239 (1969) (quoting address by Martin Luther King, Jr., Aug. 28, 1963).

19. Regents of the Univ. of Cal. v. Bakke, 438 U.S. 265, 407 (1978) (Blackmun, J., concurring).

20. A. Bickel, The Morality of Consent (1975).

21. Id. at 133. 
satisfy our theory as to how society ought to be organized . . ."22 Nonetheless, the lesson of history was ignored, and during the 1970's, the use of racial classifications became a commonplace method of satisfying an emerging, group-oriented theory as to how society ought to be organized. In the area of public education, the predominant court-ordered relief for denials of the right upheld in Brown - that is, the right to student assignments on a racially non-discriminatory basis-became mandatory raceconscious student assignments, often entailing long, involuntary bus rides to schools far from the student's home. The social issue of racial balance in the classroom-rather than the civil rights issue of racial neutrality in student assignments-became the overriding concern in school desegregation decrees, and the Supreme Court's acknowledgment in Swann that race-conscious assignments and mandatory student transportation are legitimate desegregation techniques ${ }^{23}$ evolved into nothing short of a judicial obsession with forced busing to achieve racial balance.

Rather than achieving racial balance, however, this preoccupation with mandatory busing has generally produced racial isolation on a broader scale. In case after case, economically able parents have refused to permit their children to travel unnecessary distances to attend public schools, choosing instead to enroll them in private schools or to move beyond reach of the desegregation decree. Justice Powell has commented on this phenomenon in the following terms:

This pursuit of racial balance at any cost . . . is without constitutional or social justification. Out of zeal to remedy one evil, courts may encourage or set the stage for other evils. By acting against onerace schools, courts may produce one-race school systems. ${ }^{24}$

After more than a decade of court-ordered busing, the evidence is overwhelming that the effort to desegregate through wholesale reliance on race-conscious student assignment plans has failed. The damage to public education wrought by mandatory busing is evident in city after city: Boston, Cleveland, Detroit, Wilmington, Memphis, Denver, and Los Angeles are but a few of the larger and thus more celebrated examples. Nor is it difficult to understand why. The flight from urban public schools contributes to the erosion of the municipal tax base, which in turn has a direct bearing on the growing inability of many school systems to provide a quality public education to their students-whether black or white. Simi-

22. DeFunis v. Odegaard, 416 U.S. 312, 342-44 (1974) (Douglas, J., dissenting) (emphasis added).

23. See Swann v. Charlotte-Mecklenberg Bd. of Ed., 402 U.S. 1 (1971).

24. Estes v. Metropolitan Branches of the Dallas NAACP, 444 U.S. 437, 450 (1980) (Powell, J., joined by Stewart \& Rehnquist, JJ., dissenting from dismissal of certiorari as improvidently granted). 
larly, the loss of parental support and involvement-which often comes with the abandonment of a neighborhood schools policy-has robbed many public school systems of a critical component of successful educational programs.

Mandatory busing is an excellent example of the contemporary inclination to view a group-oriented social problem-racial stratification in public schools-as a civil rights issue and to seek to solve it with coercive judicial remedies. In the process, the social problem is generally worsened, and the real civil right-the individual student's right to be free from racial discrimination in assignment-is invariably sacrificed.

Indeed, the more insistent government is on the use of racial preferences-whether in the form of quotas, goals, or any other numerical device-to correct what is perceived as an "imbalance" in our schools, our neighborhoods, our work places, or our elected bodies, the more racially polarized society becomes. Such a selection process inevitably encourages us to stereotype our fellow human beings-to view their advancements, not as hard-won achievements, but as conferred benefits. It invites us to look upon people as possessors of racial characteristics, not as the unique individuals who they are. It submerges the vitality of personality under the deadening prejudgments of race. The very purpose intended to be served is defeated, for race-based preferences cut against the grain of equal opportunity. And, while we are told repeatedly that this is temporarily necessary in the interest of achieving "equal results" among groups, let us not forget that it was the same justification (i.e., achieving "equal results") that sustained for over half a century the separate-but-equal doctrine-which likewise looked to membership in a particular racial group as an accepted basis for according individuals different treatment.

That sobering thought-the thought that we could by 1996 have come full circle-provides a ready answer to those who argue that we must use race to get beyond racism. History teaches us all too well that such an approach does not work. It is wrong when the government bestows advantages on whites at the expense of innocent blacks; it assumes no greater claim of morality if the tables are turned. More discrimination is simply not the way to end discrimination. We are all-each of us-a minority in this country: a minority of one. Our rights derive from the uniquely American belief in the primacy of the individual. And in no instance should an individual's rights rise any higher or fall any lower than the rights of others because of race, gender, or ethnic origin. Whatever group membership one inherits, it carries with it no entitlement to preferential treatment over those not similarly endowed with the same immutable characteristics. Any compromise of this principle is discrimination, plain and simple, and such behavior is no more tolerable when employed reme- 
dially, in the name of "affirmative action" or "racial balance," to bestow a gratuitous advantage on members of a particular group, than when it is divorced from such beneficence and for the most invidious of reasons works to one's disadvantage. Nor can any such compromise long endure. As Jack Greenberg put it in a law review article published in 1959, the inconsistency between "the personal right of freedom from racial discrimination" and "a group right philosophy" is "like a foreign body in the human system; there is a normal, instinctive reaction to force it out."25

To be sure, there are significant benefits our citizens obtain from attending a culturally diverse school and laboring in a multi-racial workforce. But to recognize the legitimacy of these benefits is not to justify or support racial quotas in hiring, firing, and promotions, nor to tolerate school assignments by race to achieve racial percentages.

Rather, the only sensible policy course is to expand recruitment, to reach out and include those minorities who were previously excluded, and then to judge all applicants on their individual merits, without discrimination. In education, the policy must be to expand educational opportunities with special magnet schools and other curriculum-improvement programs, and then to allow all children to attend these or other schools within the system regardless of race or residence. As Dr. Dennis L. Cuddy has noted repeatedly, with this voluntary approach, the callous injustice of racial discrimination can be cured-not by imposing burdens on innocent individuals because of color, but by reaching out to all individuals and extending them a full measure of opportunity and consideration based on merit. ${ }^{28}$

We are, I submit, at a crossroads in the development of civil rights policy in this country. We can adhere to the fundamental principles that got us this far and fight-as did the leaders of the civil rights movement in the 1960's-for the rights of individuals, or we can continue the drift in the direction of race-conscious decisionmaking, elevating the interests of particular groups above the rights-the civil rights-of their members. It is my firm belief that Professor William Van Alstyne pointed in the right direction:

[O]ne gets beyond racism by getting beyond it now: by a complete, resolute, and credible commitment never to tolerate in one's own life-or in the life or practices of one's government-the differential treatment of other human beings by race. Indeed, that is the great lesson for government itself to teach: in all we do in life, whatever

25. Greenberg, Race Relations and Group Interests in the Law, 13 RuTGERS L. REv. 503, 507 (1959).

26. Cuddy, A Proposal to Achiece Desegregation Through Free Choice, Am. Educ., May 1983, 25-31. 
we do in life, to treat any person less well than another or to favor any more than another for being black or white or brown or red, is wrong. Let that be our fundamental law and we shall have a Constitution universally worth expounding. ${ }^{27}$

If we follow that sound advice, the evil of discrimination that has plagued us for so many years can indeed begin to be discussed largely as a problem of the past, rather than as a "brooding omnipresence" that continues to haunt us for the future. If we do not, but rather continue to view group-oriented social issues as civil rights issues and to pursue colorconscious solutions, my prediction is that-as benign as the intent may be-we will advance no closer to a realization of the dream of Dr. Martin Luther King, Jr., and, indeed, could well find ourselves in 1996 in a racially ordered society similar to that approved by the Plessy Court in 1896.

I leave you with that to ponder.

27. Van Nlstyne, Rites of Passage: Race, the Supreme Court and the Constitution, 46 U. CHI. L. REv. 775, 809-10 (1979). 